\title{
Seasonal pelage color change: news based on a South American Rodent
}

\author{
CAROLINA R. CAMARGO ${ }^{1}$, ELTON COLARES $^{2}$ and ANA MARIA L. CASTRUCCI ${ }^{1,3}$ \\ ${ }^{1}$ Departamento de Fisiologia, Instituto de Biociências, Universidade de São Paulo, \\ Rua do Matão, trav. 14, 05508-900 São Paulo, SP, Brasil \\ ${ }^{2}$ Programa de Pós-graduação em Fisiologia Animal Comparada, Departamento de Ciências Fisiológicas, \\ Fundação Universidade Rio Grande, Cx. Postal 474, 96201-900 Rio Grande, RS, Brasil \\ ${ }^{3}$ Department of Biology, University of Virginia, Gilmer Hall, 485 McCormick Road, \\ Charlottesville, Virginia, 22903, USA \\ Manuscript received on January 18, 2005; accepted for publication on September 2, 2005; \\ contributed by ANA MARIA L. CASTRUCCI*
}

\begin{abstract}
Mammalian seasonal molting and color change are known to be influenced by photoperiod changes. Calomys laucha, a South American rodent, exhibits seasonal pelage color change; however, unlike Northern hemisphere rodents, which present a gray or brown color during summer and a whitish color during winter, $C$. laucha pelage changes from an orange color during summer to a dark gray color during winter. Animals maintained for over a year in stationary photoperiod $\left(\mathrm{LD} 12: 12 \mathrm{~h}, 22^{\circ} \mathrm{C}\right.$ ) presented orange pelage color during the summer corresponding month (January), and gray color during the winter corresponding month (July). Same age animals were evaluated during summer or winter months, and also showed different colors. Animals exposed for 12 weeks to summer or winter artificial conditions displayed color change, not according to the environmental conditions, as expected, but similar to that of animals maintained in stationary photoperiod. These results suggest that pelage color change in $C$. laucha is controlled by an endogenous circannual rhythm. The adaptive function of $C$. laucha color change is discussed.
\end{abstract}

Key words: Color change, endogenous rhythm, seasonality, molt, pelage color.

\section{INTRODUCTION}

Seasonal alterations in organisms are important to anticipate ambient changes and to begin adjustments to environmental modifications occurring throughout the year. In mammals, molt and weight changes prepare the animal for winter or summer. Small rodents usually exhibit photoperiod-induced molting. In Djungarian hamsters, weasels, lemmings and voles, exposure to short photoperiods induces molt to the winter pelage and exposure to long photoperiods induces molt to the summer pelage

* Member, Academia Brasileira de Ciências

Correspondence to: A.M.L. Castrucci

E-mail: amdlcast@ib.usp.br
(Duncan et al. 1985, Rust and Meyer 1969, Nagy et al. 1993, Smale et al. 1988). Minks and squirrels present an endogenous rhythm of molt which is strongly influenced by changes in photoperiod (Martinet et al. 1992) or temperature (Joy and Mrosovsky 1985). Both species also possess endogenous annual rhythms in body weight (Martinet et al. 1992, Pengelley and Asmundson 1969) as do European hamsters (Masson-Pevet et al. 1994) and dormice (Mrosovsky 1977).

Djungarian hamsters, weasels and lemmings present molt with pelage color change, but no endogenous rhythm has been demonstrated in these animals so far. The pelage changes from a whitish 
color during the winter to a pigmented color (brown, gray) during the summer (Hoffman 1973, Rust and Meyer 1969, Gower et al. 1993).

The control of molt and color change rests on the production and secretion of hormones. High levels of prolactin have been correlated to summer molt or maintenance of summer pelage in hamsters, lemmings, minks, and voles (Duncan and Goldman 1984, Gower et al. 1993, Martinet et al. 1984, Smale et al. 1990), while melatonin induces molt to the white winter pelage probably by inhibiting prolactin secretion (Lamberts and Macleod 1990; hamsters, Badura and Goldman 1992; minks, Martinet et al. 1983; lemmings, Gower et al. 1993; weasels, Rust and Meyer 1969).

Other hormones have been shown to control pigment production in mammals, acting upon the melanin biosynthetic pathway. Melanocyte stimulating hormone (MSH) stimulates eumelanin production, which has a brown to black color; while Agouti Signal Protein (ASP) promotes a switch in the melanogenic pathway and stimulates the production of red to yellow phaeomelanin (Geschwind et al. 1972, Burchill et al. 1986, Furumura et al. 1996).

Murine rodents of the Calomys genus are well distributed in South America, where they represent one of the most widespread genera of small neotropical rodent fauna (Salazar-Bravo et al. 2001). Interestingly, Calomys laucha shows a pelage color change diverse from that seen in North hemisphere small mammals: during the winter its pelage is dark gray, while during the summer the pelage exhibits a strong orange color. The aim of this work was to determine whether temperature and photoperiod conditions were the driving factors for pelage color change in Calomys laucha.

\section{MATERIALS AND METHODS}

\section{Capture And Maintenance}

Eight specimens of Calomys laucha were collected with traps at Cassino Beach in Rio Grande do Sul, Brazil, $32^{\circ} 20^{\prime} \mathrm{S} ; 52^{\circ} 10^{\prime} \mathrm{W}, 10$ kilometers away from human habitation, in October 1998. The animals live inside burrows in sand dunes, where the temperature, over the year, may vary from $0^{\circ} \mathrm{C}$ to a maximum of $50^{\circ} \mathrm{C}$ (averages of $5^{\circ} \mathrm{C}$ in winter and $29^{\circ} \mathrm{C}$ in summer), and the photoperiod changes from 14 hours of light: 10 hours of dark to 10 hours of light: 14 hours of dark. Couples (parental generation, F0) were housed to form a breeding colony in São Paulo $\left(23^{\circ} 30^{\prime} \mathrm{S} ; 46^{\circ} 12^{\prime} \mathrm{W}\right)$ in November 1998 . Temperature in animal room was maintained at $20 \pm 2^{\circ} \mathrm{C}$ and photoperiod regimen was controlled (LD 12:12h, lights on at 6:00 a.m.; off at 6:00 p.m.). Animals were kept in $35 \times 20 \times 13 \mathrm{~cm}$ plastic cages ( 2 animals per cage) containing shavings, and fed $a d l i$ bitum with water and NUVITAL rodent chow, supplemented with sunflower seeds twice a week. F1 generation was used to form 10 matrix couples. F2 generation was maintained as F0 and F1 animals, and used (both sexes separately) for the experiments starting in August 1999. Animals were maintained in the animal room until randomly assigned to one of the 5 experimental groups.

The handling, experimentation and sacrifice were performed in accordance with U.S. National Institutes of Health Guide for the Use of Laboratory Animals, and the Brazilian law no. 6638 (May 8, 1979).

\section{EXPERIMENTAL GROUPS}

Animal Room group (AR): 19 animals of varying ages, maintained in the animal room, and individually assessed as for their pelage color every two weeks from September 1999 to July 2000, after what they were sacrificed.

Summertime group (St) and Wintertime group (Wt): animals maintained from birth under the animal room conditions, assessed as for their pelage color on the exact day they were 120 day old, between December 6, 1999 and January 17, 2000 (St group, 49 animals) or between July 29 and August 3, 2000 (Wt group, 48 animals).

Artificial Summer group (AS) and Artificial Winter group $(A W)$ : 45 to 55 day old animals placed in photoperiod chambers, in different months between 
TABLE I

Ages of $A S$ and $A W$ animals when pelage color was assessed.

\begin{tabular}{|l|c|c|c|c|c|c|}
\hline Evaluations & $1^{\text {st }}$ & $2^{\text {nd }}$ & $3^{\text {rd }}$ & $4^{\text {th }}$ & $5^{\text {th }}$ & $6^{\text {th }}$ \\
\hline Age (days) & $45-55$ & $73-83$ & $87-97$ & $101-111$ & $115-125$ & $129-139$ \\
\hline
\end{tabular}

August 1999 and July 2000, assessed as for their pelage color every two weeks, after an initial 4-week period (Table I). 48 animals were exposed to LD 14:10h (lights on at 7:00 am, off at 9:00 pm; 1500 lux) and constant temperature of $35^{\circ} \mathrm{C}$ (AS group), 48 animals were exposed to LD 10:14h (lights on at 7:00 am, off at 5:00 pm; 1500 lux) and constant temperature of $10^{\circ} \mathrm{C}$ (AW group).

\section{COLOR Classification}

Pelage color was assessed by comparison of the dorsal pelage to a color plate (Villalobos-Domínguez and Villalobos 1947; plate O-orange), under 100 lux illumination. The color plate has 2 scales: chromatic degree ( 0 to 12$)$, herein called orange degree, and lightness value ( 0 to 20 ), which was inverted (20 to 0 ) in order to make graphic visualization easier, and named darkness value. Animals were individually kept in small acrylic boxes during pelage color classification, which lasted not more than $5 \mathrm{~min}$.

\section{BODY WEIGHT}

Animals from St and Wt groups were sacrificed and weighed to the nearest $0.1 \mathrm{~g}$, after pelage color evaluation.

\section{STATISTICAL ANALYSIS}

Pelage color was monitored every 2 weeks over 11 months. Frequencies were grouped by month, and the medians of each month distribution of dark value and orange degree frequencies were calculated. A frequency table and a Chi-Squared test determined AR group variation throughout the year. MannWhitney test was used to compare pelage color frequencies between sexes and between $\mathrm{St}$ and $\mathrm{Wt}$ groups. Two-Way ANOVA was used to compare body weights between sexes and between seasons. The chosen level of significance was $\alpha=0.05$.

\section{RESULTS}

\section{AR GROUP}

There were no significant differences in the dynamic of color change between males and females $(\mathrm{p}>$ 0.05 , data not shown), therefore both sexes were grouped for further analyses.

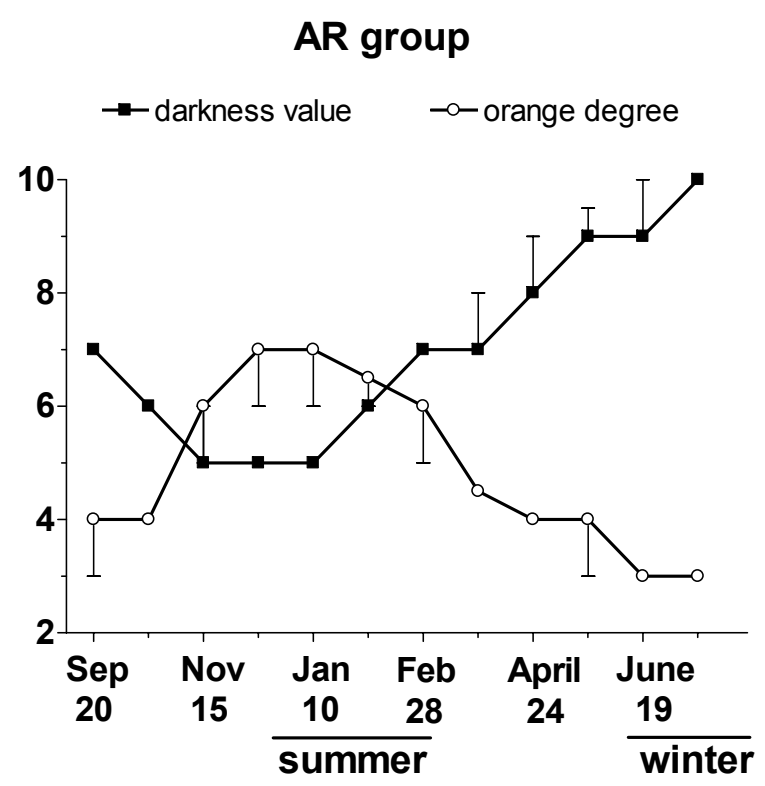

Fig. 1 - Median of darkness value and orange degree from AR group animals between September 1999 and July 2000. Bars = $25-75 \%\left(1^{\text {st }}\right.$ and $3^{\text {rd }}$ quartiles $)$.

The medians of frequency distribution of darkness value and orange degree for each month are shown in Figure 1. Although the animals were exposed to a stationary photoperiod and constant temperature for more than a year, their pelage color changed accordingly to the actual season: during summertime (December and January) their pelage 
was light orange; during wintertime (June and July) the pelage of the same animals was darker (Table II, $\chi^{2}=626.3$, degrees of freedom $=77$ ) and less orange (Table III, $\chi^{2}=401.4$, degrees of freedom $=88)$, becoming gray $(\mathrm{p}<0.0001$ for both darkness value and orange degree). All animals of this group synchronized their color changes; however during summertime they exhibited a wide dispersion of the orange degrees, not seen during wintertime. Dispersion of darkness values did not occur in any season.

Table IV shows darkness values and orange degrees of some animals from AR group, and their respective ages, in some dates along one year, demonstrating that regardless the age the animals changed pelage color according to the season.

\section{ST AND WT GROUPS}

Same age animals also presented a different pelage color during summertime and wintertime: animals from the St group were orange and light while animals from the Wt group were gray and dark $(\mathrm{p}<$ 0.0001; Fig. 2, Table V). Body weight differed significantly between groups and between sexes: $\mathrm{Wt}$ animals were heavier than St animals $(\mathrm{p}<0.0005)$ and males were heavier than females $(\mathrm{p}<0.0001$; Table VI, Fig. 3).

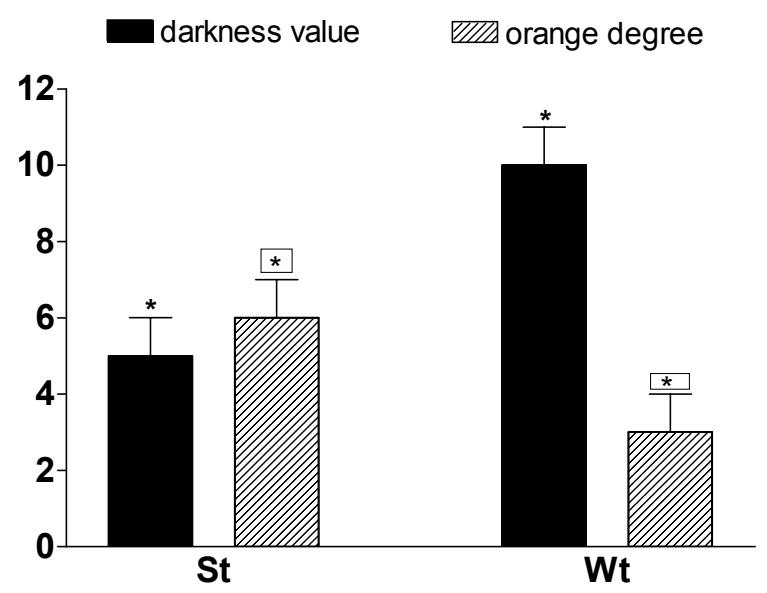

Fig. 2 - Median of St and Wt group darkness value and orange degree. $(*)$ means statistically different $(\mathrm{p}<0.0001)$. Bars $=$ $25-75 \%\left(1^{\text {st }}\right.$ and $3^{\text {rd }}$ quartiles $)$.

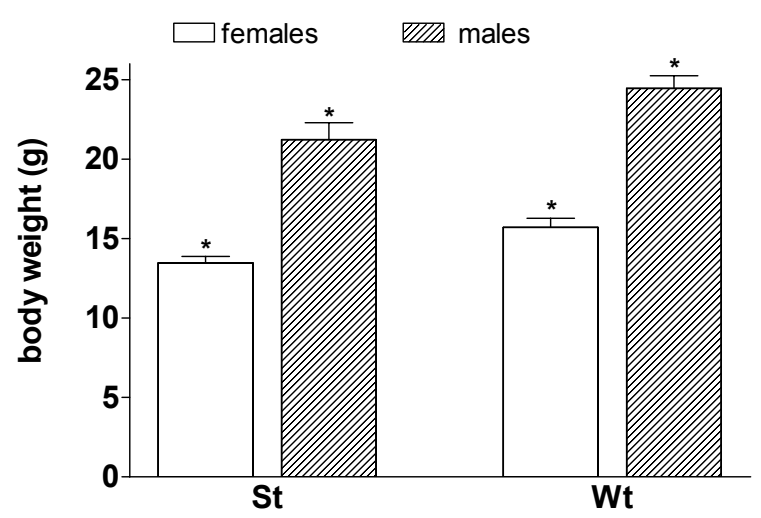

Fig. 3 - Body weight of St and Wt animals. (*) means statistically different. $\mathrm{P}<0.0001$ between sexes; $\mathrm{p}<0.0005$ between seasons.

\section{AS AND AW GROUPS}

Animals exposed for 12 weeks to artificial summer or winter conditions did not show pelage color change accordingly. On the contrary, these animals changed their pelage color as the AR animals did (Table VII). Figure 4 shows representative data from AW group at the onset of summer season.

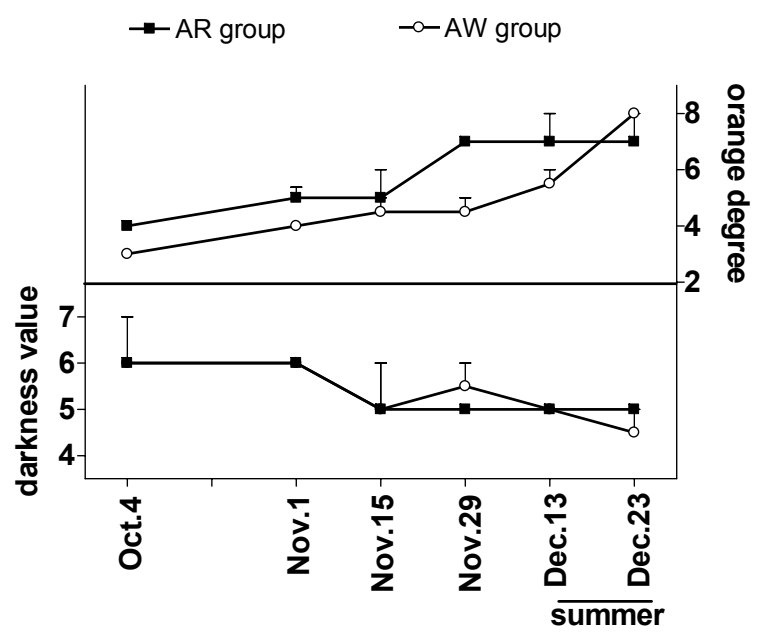

Fig. 4 - Representative graph: animals submitted to artificial winter conditions (AW group) when actual summer was coming. The dynamics of color change was similar to the AR group animals, which changed to summer pelage color. 
TABLE II

Frequency of Darkness Values from the AR group over the year, sequentially grouped by 2, with medians and quartiles (25\%-75\%). The first measurement date of each group is noted.

\begin{tabular}{|c|c|c|c|c|c|c|c|c|c|c|c|c|}
\hline Value & $\begin{array}{c}\text { Sep } \\
20\end{array}$ & $\begin{array}{c}\text { Oct } \\
18\end{array}$ & $\begin{array}{c}\text { Nov } \\
15\end{array}$ & $\begin{array}{c}\text { Dec } \\
13\end{array}$ & $\begin{array}{c}\text { Jan } \\
10\end{array}$ & $\begin{array}{c}\text { Jan } \\
31\end{array}$ & $\begin{array}{c}\text { Feb } \\
28\end{array}$ & $\begin{array}{c}\text { Mar } \\
27\end{array}$ & $\begin{array}{c}\text { Apr } \\
24\end{array}$ & $\begin{array}{c}\text { May } \\
22\end{array}$ & $\begin{array}{c}\text { Jun } \\
19\end{array}$ & $\begin{array}{c}\text { Jul } \\
17\end{array}$ \\
\hline 11 & 0 & 0 & 0 & 0 & 0 & 0 & 0 & 0 & 0 & 0 & 0 & 4 \\
\hline 10 & 0 & 0 & 0 & 0 & 0 & 0 & 0 & 0 & 2 & 9 & 13 & 19 \\
\hline 9 & 0 & 0 & 0 & 0 & 0 & 0 & 0 & 2 & 14 & 19 & 17 & 9 \\
\hline 8 & 2 & 0 & 0 & 0 & 0 & 1 & 2 & 5 & 13 & 7 & 4 & 1 \\
\hline 7 & 5 & 6 & 2 & 0 & 0 & 6 & 12 & 18 & 9 & 1 & 0 & 0 \\
\hline 6 & 4 & 14 & 7 & 2 & 6 & 12 & 12 & 1 & 0 & 0 & 0 & 0 \\
\hline 5 & 0 & 10 & 20 & 21 & 19 & 11 & 1 & 0 & 0 & 0 & 0 & 0 \\
\hline 4 & 0 & 0 & 1 & 7 & 6 & 0 & 0 & 0 & 0 & 0 & 0 & 0 \\
\hline Median & 7 & 6 & 5 & 5 & 5 & 6 & 7 & 7 & 8 & 9 & 9 & 10 \\
\hline $25-75 \%$ & $6-7$ & $5-6$ & $5-6$ & $5-5$ & $5-5$ & $5-6$ & $6-7$ & $7-8$ & $8-9$ & $9-9.5$ & $9-10$ & $9-10$ \\
\hline
\end{tabular}

$$
\chi^{2}=626.3 ; \text { degrees of freedom }=77 ; \mathrm{p}<0.0001\left(\chi_{0.05 ; 77}^{2}=98.5\right) .
$$

\section{TABLE III}

Frequency of Orange Degree from the AR group over the year, sequentially grouped by 2, with medians and quartiles (25\%-75\%). The first measurement date of each group is noted.

\begin{tabular}{|c|c|c|c|c|c|c|c|c|c|c|c|c|}
\hline Degree & 20 & 18 & 15 & 13 & 10 & 31 & 28 & 27 & 24 & 22 & 19 & 17 \\
\hline $\mathbf{2}$ & 2 & 0 & 0 & 0 & 0 & 0 & 0 & 0 & 0 & 2 & 2 & 2 \\
\hline $\mathbf{3}$ & 3 & 4 & 0 & 0 & 0 & 0 & 0 & 0 & 4 & 14 & 18 & 19 \\
\hline $\mathbf{4}$ & 5 & 13 & 4 & 0 & 0 & 2 & 6 & 13 & 23 & 17 & 11 & 12 \\
\hline $\mathbf{5}$ & 1 & 10 & 8 & 4 & 2 & 5 & 7 & 6 & 11 & 3 & 3 & 0 \\
\hline $\mathbf{6}$ & 0 & 3 & 9 & 8 & 8 & 8 & 9 & 7 & 0 & 0 & 0 & 0 \\
\hline $\mathbf{7}$ & 0 & 0 & 7 & 5 & 6 & 7 & 5 & 0 & 0 & 0 & 0 & 0 \\
\hline $\mathbf{8}$ & 0 & 0 & 2 & 10 & 7 & 4 & 0 & 0 & 0 & 0 & 0 & 0 \\
\hline $\mathbf{9}$ & 0 & 0 & 0 & 3 & 7 & 3 & 0 & 0 & 0 & 0 & 0 & 0 \\
\hline $\mathbf{1 0}$ & 0 & 0 & 0 & 0 & 1 & 1 & 0 & 0 & 0 & 0 & 0 & 0 \\
\hline Median & 4 & 4 & 6 & 7 & 7 & 6.5 & 6 & 4.5 & 4 & 4 & 3 & 3 \\
\hline $\mathbf{2 5 \% - 7 5 \%}$ & $3-4$ & $4-5$ & $5-7$ & $6-8$ & $6-9$ & $6-8$ & $5-6$ & $4-6$ & $4-5$ & $3-4$ & $3-4$ & $3-4$ \\
\hline
\end{tabular}


TABLE IV

Examples of Darkness Value and Orange Degree of some animals from AR group, and their respective ages, in some dates along one year.

\begin{tabular}{|c|c|c|c|c|c|c|}
\hline \multicolumn{7}{|c|}{ Darkness Values (age in days between parentheses) } \\
\hline ANIMAL & Nov 1 & Dec 23 & Jan 17 & Mar 27 & May 22 & Jul 31 \\
\hline $\mathbf{1 2 0}$ & $14(177)$ & $14.5(229)$ & $14.5(254)$ & $12(324)$ & $10(370)$ & $10(440)$ \\
\hline $\mathbf{1 1 4}$ & $14(192)$ & $15(244)$ & $15(269)$ & $13(339)$ & $11(385)$ & $10(455)$ \\
\hline $\mathbf{2 5 8}$ & $15(67)$ & $16(119)$ & $15(144)$ & $13(214)$ & $12(260)$ & $11(320)$ \\
\hline $\mathbf{2 6 7}$ & $14(51)$ & $16(103)$ & $16(128)$ & $13(198)$ & $12(244)$ & $10(304)$ \\
\hline \multicolumn{7}{|c|}{ Orange Degrees (age in days between parentheses) } \\
\hline ANIMAL & Nov 1 & Dec 23 & Jan 17 & Mar 27 & May 22 & Jul 31 \\
\hline $\mathbf{1 2 0}$ & $5(177)$ & $7(229)$ & $8(254)$ & $5(324)$ & $4(370)$ & $3(440)$ \\
\hline $\mathbf{1 1 4}$ & $4(192)$ & $6(244)$ & $7.5(269)$ & $4.5(339)$ & $4(385)$ & $3(455)$ \\
\hline $\mathbf{2 5 8}$ & $5.5(67)$ & $8(119)$ & $10(144)$ & $6(214)$ & $5(260)$ & $4(320)$ \\
\hline $\mathbf{2 6 7}$ & $4(51)$ & $8(103)$ & $9(128)$ & $5(198)$ & $4(244)$ & $3(304)$ \\
\hline
\end{tabular}

TABLE V

Medians of St and Wt groups for Darkness Value and

Orange Degree, with quartiles (25-75\%).

\begin{tabular}{|c|c|c|}
\hline Group & Darkness value* $^{*}$ & Orange degree* $^{*}$ \\
\hline St median & 5 & 6 \\
\hline $\mathbf{2 5 \% - 7 5 \%}$ & $5-6$ & $5-7$ \\
\hline Wt median & 10 & 3 \\
\hline $\mathbf{2 5 \% - 7 5 \%}$ & $10-9$ & $3-4$ \\
\hline
\end{tabular}

$(*) \mathrm{p}<0.0001$.

\section{DISCUSSION}

Our results place Calomys laucha among the mammals whose pelage color changes rhythmically throughout the year. However, the seasonal molt and color change seen in this species was not strongly influenced by summer or winter environmental conditions. Animals from both sexes maintained at stationary photoperiod regimen and controlled temperature for over a year (AR group) presented pelage color change, even away from the natural environment. These animals became orange and light during the months corresponding to summertime, and gray and dark during the months corresponding to wintertime. Clearly, aging is not involved in this process of color change, since the pelage color varied according the time of the year, regardless the animal age.

The dynamic of pelage color change was not affected by exposure for at least 12 weeks to summer or winter photoperiods and temperatures similar to those experienced in natural habitat. When exposed to short photoperiod and low temperature (AW group), animals continued the process of color change accordingly to the time of the year, achieving the summer pelage color. Similarly, animals exposed to long photoperiod and high temperatures (AS group) acquired the winter pelage color in an- 
TABLE VI

St and Wt animals Body Weight (g), for females and males. Values are means $( \pm$ SEM).

\begin{tabular}{|c|c|c|c|c|}
\hline & Females ** & & Males ** & \\
\hline Groups & Weight $(\mathrm{g})$ & $\mathrm{N}$ & Weight $(\mathrm{g})$ & $\mathrm{N}$ \\
\hline St $*$ & $13.5 \pm 0.4$ & 27 & $21.2 \pm 1.1$ & 22 \\
\hline Wt $*$ & $15.7 \pm 0.6$ & 24 & $24.5 \pm 0.8$ & 33 \\
\hline
\end{tabular}

(*) $\mathrm{p}<0.0005 ;(* *) \mathrm{p}<0.0001$.

\section{TABLE VII}

Representative data of AW group. Darkness Value and Orange Degree from AW group, maintained for 12 weeks in winter conditions when Summer season was coming, and AR group values for the same dates (medians and quartiles (25\%-75\%)).

\begin{tabular}{|c|c|c|c|c|c|c|}
\hline Groups & Oct. 4 & Nov.1 & Nov. 15 & Nov.29 & Dec.13 & Dec.23 \\
\hline Darkness value & & & & & & \\
\hline AW median & 6 & 6 & 5 & 5.5 & 5 & 4.5 \\
\hline $25 \%-75 \%$ & $6-6$ & $6-6$ & $5-6$ & $5-6$ & $5-5$ & $4-5$ \\
\hline AR median & 6 & 6 & 5 & 5 & 5 & 5 \\
\hline $25 \%-75 \%$ & $6-7$ & $5-6$ & $5-6$ & $5-5$ & $4.5-5$ & $4-5$ \\
\hline Orange degree & & & & & & \\
\hline AW median & 3 & 4 & 4.5 & 4.5 & 5.5 & 8 \\
\hline $25 \%-75 \%$ & $3-3$ & $4-4$ & $4-5$ & $4-5$ & $5-6$ & $7-8$ \\
\hline AR median & 4 & 5 & 5 & 7 & 7 & 7 \\
\hline $25 \%-75 \%$ & $4-4$ & $4-5.5$ & $5-6$ & $6-7$ & $6-8$ & $6-8$ \\
\hline
\end{tabular}

ticipation of the wintertime. The progress of color change was not reversed as expected, unlike lemmings, hamsters and minks which present partial molt and color change accordingly to the photoperiod they were exposed for the same period of time, 12 weeks (Gower et al. 1993, Duncan and Goldman 1984, Martinet et al. 1984).

Taken together, these results suggest that Calomys laucha may have an endogenous circannual rhythm that controls pelage color change, and that photoperiod and temperature have apparently little influence on the rhythm. Circannual rhythms of molting occur in squirrels and minks (Davis and Swade 1983, Martinet et al. 1992). In these animals, the summer and winter pelts mainly differ in pelage type and density (Rust et al. 1965, Walsberg et al. 1997), and the photoperiod regimen seems to be the zeitgeber for minks (Martinet et al. 1992) while temperature, rather than photoperiod, the zeitgeber for squirrels (Joy and Mrosovsky 1985).

Besides color change, Calomys laucha also presented an apparently endogenous body weight variation as it seems to happen in squirrels, minks and European hamsters (Pengelley and Asmundson 1969, Martinet et al. 1992, Masson-Pevet et al. 1994), since Wt animals were heavier than St animals, even without contact with the natural environment. 
The pattern of color change in C. laucha differs from other mammals. Animals which display pelage color changes become pigmented during the summer, due to melanin production by the hair bulb melanocytes. During the winter molt, the pigment production stops or is highly reduced, and as a consequence, the hair and coat turn white. In C. laucha, there is no arrest of pigment production, but a change of melanin type. During the summer molt there might be a high production of phaeomelanin and low production of eumelanin, since the animals become orange and lighter, whereas during the winter molt a high production of eumelanin and low production of phaeomelanin lead to a gray and darker pelage.

The rhythm of color change may reflect a rhythm of the hormones that regulate pigment production and molt, such as melatonin and prolactin, and of the hormones which control the switch in the melanin biosynthetic pathway, as MSH and ASP. Their secretion and release is most probably controlled, directly or indirectly, by the endogenous clock. However their role in this process seems to partially differ from Northern mammals, since $C$. laucha pelage becomes darker during the winter and not during the summer.

Several experimental studies lead to the view that pelage color in small mammals may have a cryptic function to avoid predation, even in species which spend most of their life underground (Heth et al. 1988). Background matching may also be the adaptive function of Calomys laucha color change. During summer, the animal feeds in the sand dunes, in which the light orange fur would be cryptic; in the winter, when food supplies decreases, C. laucha gets closer to human housing, therefore adapted to mimic dark soils and the brown log houses. One should also remember that thermoregulation may also play a role, as winter darker coat conveys more energy to increase body temperature.

To our knowledge, this is the first report of an endogenous circannual cycle of pelage color change, upon which photoperiod and temperature regimens seem to exert little or no influence. The body weight change is also probably driven by an endogenous circannual rhythm, but the effects of photoperiod and temperature are still to be further investigated.

\section{ACKNOWLEDGMENTS}

This research was supported by Fundação de Amparo à Pesquisa do Estado de São Paulo (FAPESP, grant 01/02460-1), and Conselho Nacional de Desenvolvimento Científico e Tecnológico (CNPq, grant 522969/96-8). CRC was a fellow of FAPESP (97/14515-8). We are thankful to Dr. Miriam D. Marques and Dr. Luiz E.M. Nery for helpful advices and discussion, and to Telma Pazzini for her technical assistance.

\section{RESUMO}

A muda e a mudança de cor sazonal da pelagem de mamíferos são influenciadas por variações no fotoperíodo. Calomys laucha, um roedor sul-americano, exibe mudança de cor de pelagem sazonal; entretanto, diferentemente dos roedores do hemisfério Norte, os quais apresentam cor cinza ou marrom durante o verão e branca durante o inverno, a pelagem de $C$. laucha muda de uma cor alaranjada durante o verão para cinza escuro durante o inverno. Animais mantidos por mais de um ano em fotoperíodo estacionário (CE $\left.12: 12 \mathrm{~h}, 22^{\circ} \mathrm{C}\right)$ apresentaram pelagem alaranjada durante o mês correspondente ao verão (Janeiro), e cor cinza durante o mês de inverno (Julho). Animais de mesma idade foram avaliados durante os meses de verão ou inverno, e também apresentaram pelagem de cores diferentes. Animais expostos a condições artificiais de verão ou de inverno durante 12 semanas sofreram mudança de cor da pelagem, não de acordo com as condições ambientais a que estavam sujeitos como esperado, mas exibiram a mesma cor dos animais mantidos em fotoperíodo estacionário. Estes resultados sugerem que a mudança de cor da pelagem de $C$. laucha é controlada por um ritmo endógeno circanual.

Palavras-chave: Mudança de cor, ritmo endógeno, sazonalidade, muda, cor da pelagem. 


\section{REFERENCES}

BADURA LL AND GOLdMAN BD. 1992. Prolactindependent seasonal changes in pelage: role of the pineal gland and dopamine. J Exp Zool 261: 27-33.

Burchill SA, Thody AJ AND ITO S. 1986. Melanocyte-stimulating hormone, tyrosinase activity and the regulation of eumelanogenesis and phaeomelanogenesis in the hair follicular melanocytes of the mouse. J Endocrinol 109: 15-21.

DAVIS DE AND SWADE RH. 1983. Circannual rhythm of torpor and molt in the ground squirrel, Spermophilus beecheyi. Comp Biochem Physiol 76A: 183-187.

DUNCAN MJ AND GOLDMAN BD. 1984. Hormonal regulation of the annual pelage color cycle in the Djungarian hamster, Phodopus sungorus. II. Role of prolactin. J Exp Zool 230: 97-103.

Duncan MJ, Goldman BD, Di Pinto MN AND SteTsON MH. 1985. Testicular function and pelage color have different critical daylenghts in the Djungarian hamster, Phodopus sungorus sungorus. Endocrinology 116: 424-430.

Furumura M, Sakai C, Abdel-Malek Z, Barsh GS AND HEARING VJ. 1996. The interaction of agouti signal protein and melanocyte stimulating hormone to regulate melanin formation in mammals. Pigment Cell Res 9: 191-203.

Geschwind II, Huseby RA And Nishioka R. 1972. The effect of melanocyte-stimulating hormone on coat color in the mouse. Rec Prog Horm Res 28: 91-130.

Gower BA, NAgy TR And Stetson MH. 1993. Role of prolactin and the gonads in seasonal physiological changes in the collared lemming (Dicrostonyx groenlandicus). J Exp Zool 266: 92-101.

Heth G, Beiles A And Nevo E. 1988. Adaptive variation of pelage color within and between species of the subterranean mole rat (Spalax ehrenbergi) in Israel. Oecologia 74: 617-622.

HofFMAN K. 1973. The influence of photoperiod and melatonin on testis size, body weight, and pelage colour in the Djungarian hamster (Phodopus sungorus). J Comp Physiol 85: 267-282.

JOY JE AND Mrosovsky N. 1985. Synchronization of circannual cycles: a cold spring delays the cycles of thirteen-lined ground squirrels. J Comp Physiol A 156: 125-134.

LAmberts SWJ AND MACLEOd RM. 1990. Regulation of prolactin secretion at the level of the lactotroph. Physiol Rev 70: 291-318.

Martinet L, Allain D And Meunier M. 1983. Regulation in pregnant mink (Mustela vision) of plasma progesterone and prolactin concentrations and regulation of onset of the spring moult by daylight ratio and melatonin injections. Can J Zool 61: 1859-1963.

Martinet L, Allain D and Weiner C. 1984. Role of prolactin in the photoperiodic control of moulting in the mink (Mustela vision) J Endocrinol 103: 9-15.

Martinet L, Mondain-Monval M And MonNERIE R. 1992. Endogenous circannual rhythms and photorefractoriness of testis activity, moult and prolactin concentrations in mink (Mustela vision). J Reprod Fert 95: 325-338.

Masson-Pevet M, Naimi F, Canguihem B, Saboureau M, Bonn D and Pevet P. 1994. Are the annual reproductive and body-weight rhythms in the male european hamster (Cricetus cricetus) dependent upon a photoperiodically entrained circannual clock? J Pineal Res 17: 151-163.

MrosovsKY N. 1977. Hibernation and body weight in dormice: a new type of endogenous cycle. Science 196: 902-903.

NAGy TR, Gower BA AND Stetson MH. 1993. Threshold photoperiods for the induction of short day traits in collared lemmings (Dicrostonyx groenlandicus). J Exp Zool 267: 57-66.

Pengelley ET AND Asmundson SM. 1969. Freerunning periods of endogenous circannian rhythms in the golden mantled ground squirrel, Citellus lateralis. Comp Biochem Physiol 30: 177-183.

RUST CC AND MEYER RK. 1969. Hair color, molt, and testis size in male, short-tailed weasels treated with melatonin. Science 165: 921-922.

Rust CC, SHACKELFORd RM AND MEYER RK. 1965. Hormonal control of pelage cycles in the mink. J Mammal 46: 549-565.

Salazar-Bravo J, Dragoo JW, Tinnin DS AND YATES TL. 2001. Phylogeny and evolution of the neotropical rodent genus Calomys: Inferences from 
mitochondrial DNA sequence data. Mol Phylogenetics Evol 20: 173-184.

Smale L, Nelson RJ And Zucker I. 1988. Day length influences pelage and plasma prolactin concentrations but not reproduction in the prairie vole, Microtus ochrogaster. J Reprod Fert 83: 99-106.

Smale L, LeE TM, Nelson R And ZuCKer I. 1990. Prolactin counteracts effects of short day lengths on pelage growth in the meadow vole, Microtus pennsylvanicus. J Exp Zool 253: 186-188.
Villalobos-Domínguez C And Villalobos J. 1947. Atlas de los Colores. El Ateneo, Buenos Aires, Argentina.

Walsberg GE, Weaver T AND Wolf BO. 1997. Seasonal adjustment of solar heat gain independent of coat coloration in a desert mammal. Physiol Zool 70: $150-157$. 